Bangladesh J. Bot. 48(2): 315-320, 2019 (June)

\title{
PHYTOCHEMICAL CONTENTS AND ANTIOXIDANT ACTIVITIES OF FERN, ASPLENIUM CETERACH L. IN DIFFERENT ALTITUDES
}

\author{
Asuman Karadeniz PekgöZ* and Ilker Çinbilgel ${ }^{1}$ \\ Department of Biology, Faculty of Science and Art, Mehmet Akif Ersoy University, \\ Burdur, Turkey
}

Keywords: Phytochemical contents, Antioxidant activities, Altitude, Asplenium ceterach, Radical scavenging activity

\begin{abstract}
Phytochemical contents and antioxidant activities of fern (Asplenium ceterach L.) distributed in different altitudes ( 22 stations) were compared and the relationships between altitude and plant chemical contents were studied. The highest 2,2-diphenyl-1-picrylhydrazyl (DPPH) radical scavenging activity was found in $22^{\text {nd }}$ station $\left(\mathrm{IC}_{50}=47.91 \mu \mathrm{g} / \mathrm{ml}\right)$ and the highest total phenolic content was found in $9^{\text {th }}$ station $(110.62$ $\mu \mathrm{gGAE} / \mathrm{ml})$ whereas the maximum total flavonoid content was found in $20^{\text {th }}$ station $(232.67 \mu \mathrm{gCE} / \mathrm{ml})$. High performance liquid chromatography (HPLC) analysis indicates that the maximum pterosin $\mathrm{b}(0.235 \mu \mathrm{g} / \mathrm{ml})$, catechin $(2.756 \mu \mathrm{g} / \mathrm{ml})$ and quercetin $(0.207 \mu \mathrm{g} / \mathrm{ml})$ values were found in $21^{\text {th }}$ station whereas the maximum chlorogenic acid $(17.718 \mu \mathrm{g} / \mathrm{ml})$ was obtained in $9^{\text {th }}$ and caffeic acid $(6,598 \mu \mathrm{g} / \mathrm{ml})$ in $13^{\text {th }}$ stations. It was observed that altitude is not potent alone, but it can be a factor in the occurrence of other ecological factors like soil properties, water, humidity, light and temperature.
\end{abstract}

\section{Introduction}

Plants are used in drug development and food research all over the world and thus the studies on plant chemistry and its relation to ecological factors are increasing day by day. Plant chemical content depends not only on plant genetic and other biotic factors but also on abiotic factors such as altitude, temperature, wind and light. Because altitude can affect such factors like light, wind and temperature; anatomical, morphological, physiological and biochemical properties of the plants which could be variable. Some reports have shown that secondary metabolite contents of the plants can increase (Dong et al. 2011, Mahdavi et al. 2013), or decrease (Giuliani et al. 2013, Uniyal 2013) with altitude or basically not (Verma et al. 2013). Since flavonoids and chlorogenic acids belonging to phenolic consituents of the plants have orto-hydroxylated constructions, they have abilities to absorb light and to scavenge free radicals. These properties can explain that flavonoid contents are higher in the higher altitudes which exposed to higher U.V. radiation (Dong et al. 2011). In a study on fern, Pteridium caudatum (L.) Maxon, it was shown that it has higher phenolic content and radical scavenging ability as it is grown in higher altitudes (Alonso-Amelot et al. 2004, 2007).

Since ferns, have secondary metabolites, they are used as folk medicines. Ferns contain sesquiterpenoids, flavonoids, cyanogenic glycosides, phenolic acids and pterosins (Alonso-Amelot et al. 1992, Zivkovic et al. 2010, Chen et al. 2015). Pterosins are carcinogens for human and animals (Gil da Costa et al. 2012) but these substances play a role in activation of protein kinases activated by adenosine monophosphate which adjusts blood glycose (Chen et al. 2015). Previously antioxidant activity of some Turkish medicinal plants was studied by Karadeniz et al. (2015).

Asplenium ceterach L. (golden herb) is a fern belonging to Aspleniaceae, which is used as a folk medicine in different regions of the world. The aim of the present study was to compare the effects of different altitudes on phytochemistry and antioxidant activity of A. ceterach L.

*Author for correspondence: <asumankaradeniz@gmail.com>. ${ }^{1}$ Department of Tourism Guidance, Faculty of Manavgat Tourism, Akdeniz University, Antalya, Turkey. 


\section{Materials and Methods}

Fresh fern (Asplenium ceterach L.) samples were collected from their natural distribution areas from 22 stations in different altitudes in Burdur and Antalya provinces, Turkey, in MarchMay 2016 (Table 1). Some of the plant samples were dried in shade and cool place and the other part of the samples were saved as herbarium material after drying and pressing and preserved as vaucher specimen. Plant names were verified from the sources such as Flora of Turkey and the East Agean Islands (Davis 1965-1985), Turkish Plant List (Güner et al. 2012), The Plant List, Euro Med Plant Base, The International Plant Names Index.

Table 1. Location, date, habitat and altitude of collected fern samples.

\begin{tabular}{|c|c|c|c|c|}
\hline Station & $\begin{array}{l}\text { Collection } \\
\text { date }\end{array}$ & Province & Habitat & $\begin{array}{l}\text { Altitude } \\
\text { (m) }\end{array}$ \\
\hline 1 & 11.03 .2016 & Antalya & Humid rocky places in stream sides & 605 \\
\hline 2 & 14.04 .2016 & $"$ & Rocky places in mixed Juniperus excelsa forest & 1436 \\
\hline 3 & 15.04 .2016 & $"$ & Rocky places in mixed black pine forest & 1200 \\
\hline 4 & 15.04 .2016 & $"$ & Rocky places in maquis & 646 \\
\hline 5 & 21.04 .2016 & Burdur & Rocky places in maquis & 807 \\
\hline 6 & 21.04.2016 & $"$ & Rocky places in Quercus coccifera maquis & 906 \\
\hline 7 & 21.04 .2016 & $"$ & Rocky places in mixed Cedrus libani forest with black pine & 1488 \\
\hline 8 & 22.04 .2016 & $"$ & Rocky places in black pine forest & 1880 \\
\hline 9 & 22.04 .2016 & $"$ & Rocky places in mixed Cedrus libani forest & 1479 \\
\hline 10 & 22.04.2016 & $"$ & Rocky places in maquis & 1155 \\
\hline 11 & 5.05 .2016 & Antalya & Rocky places in red pine forest & 692 \\
\hline 12 & 5.05 .2016 & $"$ & Rocky places in red pine forest & 397 \\
\hline 13 & 6.05 .2016 & $"$ & Rocky places in red pine forest & 181 \\
\hline 14 & 6.05 .2016 & $"$ & Humid rocky places in Juniperus excelsa forest & 1330 \\
\hline 15 & 6.05 .2016 & $"$ & Rocky places in Quercus coccifera maquis & 10 \\
\hline 16 & 14.05 .2016 & $"$ & Rocky places in maquis zone & 1006 \\
\hline 17 & 12.03 .2016 & $"$ & Rocky places in red pine forest & 536 \\
\hline 18 & 14.04 .2016 & $"$ & Rocky places in red pine forest & 744 \\
\hline 19 & 21.04.2016 & Burdur & Rocky places in maquis & 846 \\
\hline 20 & 21.04 .2016 & $"$ & Rocky places in maquis & 807 \\
\hline 21 & 21.04 .2016 & Burdur & Rocky places in maquis & 1127 \\
\hline 22 & 5.05 .2016 & Antalya & Rocky places in red pine forest & 567 \\
\hline
\end{tabular}

Air dried $0.5 \mathrm{~g}$ plant sample was homogenized in a blender and extracted within $100 \mathrm{ml}$ methanol by using magnetic stirrer for a $4 \mathrm{hrs}$ and filtered with Whatman No.1 filter paper. Extracts were used within two days to detect antioxidant capacity.

The method of Blois(1958) was used with some modifications to detect DPPH (2,2-diphenyl1-picrylhydrazyl) radical scavenging activity. DPPH $(50 \mu \mathrm{l}, 1 \mathrm{mM})$ solution was added to methanol solution $(200 \mu \mathrm{l})$ of the samples or the control at various concentrations. The reaction 
mixture was shaken vigorously and the absorbance of remaining DPPH was measured at $517 \mathrm{~nm}$ after 30 min. Radical scavenging activity (inhibition percentage) was detected by comparing the absorbance with that of the blank containing only DPPH and solvent. Ascorbic acid was used as the positive control. All analyses were done in triplicates. Inhibition percentage was calculated by using the formula below:

Inhibition percentage $=\left[\left(\mathrm{Abs}_{\text {control }}-\mathrm{Abs}_{\text {sample }}\right) / \mathrm{Abs}_{\text {control }}\right] \times 100$

Radical scavenging activity (inhibitory concentration) was expressed as $\mathrm{IC}_{50}$ of the extract. The method of Singleton and Rossi(1965) was used with some modifications to detect the total phenolic content of extracts by using the Folin-Ciocalteu reagent: $10 \mu \mathrm{l}$ of sample or the standard (10 - $500 \mu \mathrm{g} / \mathrm{mlgallic}$ acid) and additionally $150 \mu \mathrm{l}$ of diluted Folin-Ciocalteu reagent $(1: 4$, reagent : water) was placed in each well of a 96-well plate and incubated at room temperature for $3 \mathrm{~min}$. Following the addition of $50 \mu \mathrm{l}$ of saturated sodium carbonate $(7.5 \%)$ and a further incubation of $2 \mathrm{hrs}$ at room temperature, absorbance was read at $725 \mathrm{~nm}$. Total phenolic content was expressed as gallic acid equivalent $(\mu \mathrm{gGAE} / \mathrm{ml})$.

The method of Zhishen et al.(1999) was used to detect total flavonoid content. Briefly, $10 \mu \mathrm{l}$ of 5\% sodium nitrite was added to the $10 \mu \mathrm{l}$ sample, after $5 \min 10 \mu 110 \%$ aluminum chloride, $150 \mu 11 \mathrm{M}$ sodium hydroxide and $50 \mu \mathrm{l}$ ultra-pure water were added. Plate was mixed well. Then the absorbance was read at $510 \mathrm{~nm}$ in UV/vis spectrophotometer. The $70 \%$ methanol was used as control. Total flavonoid content was expressed as catechin equivalent $(20-100 \mu \mathrm{gCE} / \mathrm{ml})$.

HPLC analysis of phenolics (chlorogenic acid, caffeic acid, quercetin, catechin) and pterosin b were done in Mehmet Akif Ersoy University, Scientific and Technology Application and Research Center following the modified method of Gomes et al. (1999). System: Shimadzu Prominence, Detector: DAD (SPD-M20A), Column Oven: CTO-10ASVp, Pomp: LC20 AT, Autosampler: SIL 20ACHT, Computer Programme: LC Solution, Mobile Phase: A: \%3 Formic acid B: Metanol.

All samples were analyzed in triplicates. Data are expressed as means \pm standard deviations. Descriptive statistical analysis with graphics of inhibition percentage and of the linear regression curve were made by using Microsoft Office Excel 2007 program. To determine the relationship between two variables Pearson correlation coefficients (r) were also calculated. Statistical analysis was performed using SPSS (IBM SPSS Statistics 17 Portable) and Minitab (Minitab 18) programs.

\section{Results and Discussion}

The highest DPPH radical scavenging activity and the lowest $\mathrm{IC}_{50}$ value $\left(\mathrm{IC}_{50}=47.91 \mu \mathrm{g} / \mathrm{ml}\right)$ determined in the plant extracts collected from $22^{\text {nd }}$ station are presented in Table 2 . The lowest $\mathrm{IC}_{50}$ indicated the highest radical scavenging activity, it means the extract is effective in lower concentrations (50\% of the radical can be scavenged by the extract). $\mathrm{IC}_{50}$ values of the plant extracts collected from different stations showed significant differences $(\mathrm{p} \leq 0.05)$. Tukey multiple range test showed that the extract collected from $22^{\text {th }}$ station is significantly different from the others $(\mathrm{p} \leq 0.05)$. One way ANOVA showed that $\mathrm{IC}_{50}$ values of the extracts collected from the stations in Burdur and Antalya provinces were not found significant $(\mathrm{p}>0.05)$. Pearson correlation test showed that the weak correlation $(r=0.211)$ was obtained between altitude and $\mathrm{IC}_{50}$ values which was not significant ( $\left.\mathrm{p}>0.05\right)$.

The highest total phenolic content was obtained in the plant extracts collected from $9^{\text {th }}$ station $(110,62 \mu \mathrm{g} \mathrm{GAE} / \mathrm{ml})$. Total phenolic contents of the plant extracts collected from different stations showed significant differences $(\mathrm{p} \leq 0.05)$ (Table 2). Tukey multiple range test showed that the extract collected from $9^{\text {th }}$ station is not significantly different from others $(p>0.05)$. One way ANOVA showed that total phenolic contents of the extracts collected from the stations in Burdur 
and Antalya provinces were not significantly different $(\mathrm{p}>0.05)$. Pearson correlation test observed that negatively weak correlation $(r=-0.106)$ between altitude and total phenolic content was obtained not significant ( $\mathrm{p}>0.05)$.

Table 2. DPPH radical scavenging activity, total phenolic and flavonoid contents and HPLC analysis of fern extracts collected from different stations.

\begin{tabular}{|c|c|c|c|c|c|c|c|c|}
\hline \multicolumn{4}{|c|}{ Antioxidant activity } & \multicolumn{5}{|c|}{ HPLC analysis $(\mu \mathrm{g} / \mathrm{ml})$} \\
\hline Station & $\begin{array}{c}\text { DPPH RSA } \\
\left(\mathrm{IC}_{50}\right) \\
(\mu \mathrm{g} / \mathrm{ml})^{*}\end{array}$ & $\begin{array}{c}\text { Total phenolic } \\
\text { content } \\
(\mu \mathrm{gGAE} / \mathrm{ml}) *\end{array}$ & $\begin{array}{c}\text { Total flavonoid } \\
\text { content } \\
(\mu \mathrm{gCE} / \mathrm{ml}) *\end{array}$ & $\begin{array}{c}\text { Pterosin } \\
\text { B }\end{array}$ & $\begin{array}{l}\text { Cate- } \\
\text { chin }\end{array}$ & $\begin{array}{l}\text { Chloro- } \\
\text { genic } \\
\text { acid }\end{array}$ & $\begin{array}{c}\text { Caffeic } \\
\text { acid }\end{array}$ & $\begin{array}{l}\text { Quer- } \\
\text { cetin }\end{array}$ \\
\hline St1 & $184.56 \pm 3.15$ & $66.41 \pm 3.28$ & $178.89 \pm 12.41$ & 0.094 & 1.327 & 0.085 & 0.193 & 0.125 \\
\hline St2 & $230.25 \pm 4.99$ & $68.90 \pm 3.54$ & $99.11 \pm 11.19$ & 0.051 & 1.979 & 10.371 & 0.008 & 0.129 \\
\hline St3 & $249.87 \pm 5.77$ & $62.00 \pm 3.68$ & $119.11 \pm 6.33$ & 0.056 & 1.529 & 6.405 & 0.057 & 0.143 \\
\hline St4 & $237.35 \pm 5.87$ & $75.59 \pm 6.99$ & $90.44 \pm 8.22$ & 0.046 & 1.759 & 10.453 & 0.097 & 0.122 \\
\hline St5 & $294.66 \pm 3.4$ & $50.00 \pm 3.44$ & $160.89 \pm 21.48$ & 0.098 & 1.176 & 17.042 & 5.868 & 0.14 \\
\hline St6 & $179.79 \pm 2.83$ & $62.28 \pm 3.40$ & $87.56 \pm 12.80$ & 0.09 & 0.874 & 13.4 & 0.293 & 0.143 \\
\hline St7 & $209.7 \pm 9.86$ & $62.62 \pm 9.56$ & $117.56 \pm 8.77$ & 0.116 & 0.492 & 13.758 & 0.728 & 0.132 \\
\hline St8 & $213.59 \pm 4.74$ & $74.55 \pm 9.85$ & $161.56 \pm 20.73$ & 0.063 & 0.983 & 13.103 & 0.65 & 0.136 \\
\hline St9 & $204.96 \pm 6.64$ & $110.62 \pm 10.70$ & $125.33 \pm 12.83$ & 0.079 & 0.718 & 17.718 & 1.452 & 0.125 \\
\hline St10 & $223.56 \pm 6.62$ & $97.10 \pm 8.27$ & $208.22 \pm 15.64$ & 0.084 & 0.645 & 8.938 & 1.48 & 0.121 \\
\hline St11 & $223.86 \pm 5$ & $49.93 \pm 3.33$ & $74.89 \pm 7.26$ & 0.062 & 0.549 & 13.666 & 3.258 & 0.165 \\
\hline St12 & $192.03 \pm 3.74$ & $70.90 \pm 7.21$ & $116.44 \pm 23.67$ & 0.073 & 0.438 & 7.719 & 4.081 & 0.163 \\
\hline St13 & $223.48 \pm 0.7$ & $104.48 \pm 7.47$ & $104.22 \pm 9.32$ & 0.058 & 2.203 & 15.143 & 6.598 & 0.148 \\
\hline St14 & $221.98 \pm 9.57$ & $67.45 \pm 7.92$ & $143.78 \pm 10.73$ & 0.053 & 0.519 & 11.462 & 2.478 & 0.164 \\
\hline St15 & $197.95 \pm 3.9$ & $94.83 \pm 7.88$ & $198.44 \pm 7.92$ & 0.064 & 0.292 & 8.183 & 2.424 & 0.123 \\
\hline St16 & $180.12 \pm 5.25$ & $60.21 \pm 1.48$ & $156.22 \pm 20.91$ & 0.034 & 0.15 & 6.933 & 0.332 & 0.142 \\
\hline St17 & $127.21 \pm 3.37$ & $48.83 \pm 5.71$ & $100.22 \pm 12.98$ & 0.066 & 0.179 & 5.31 & 2.434 & 0.172 \\
\hline St18 & $100.06 \pm 4.65$ & $76.41 \pm 8.02$ & $158.22 \pm 10.70$ & 0.049 & 0.12 & 6.043 & 2.086 & 0.124 \\
\hline St19 & $165.55 \pm 5.77$ & $63.17 \pm 4.17$ & $185.33 \pm 22.53$ & 0.04 & 0.234 & 2.33 & 1.818 & 0.141 \\
\hline St20 & $138.46 \pm 7.39$ & $56.00 \pm 4.06$ & $232.67 \pm 18.53$ & 0.058 & 0.711 & 11.513 & 3.42 & 0.141 \\
\hline St21 & $143.44 \pm 5.49$ & $43.10 \pm 6.10$ & $167.56 \pm 14.92$ & 0.235 & 2.756 & 11.556 & 1.618 & 0.207 \\
\hline St22 & $47.91 \pm 15.03$ & $88.14 \pm 22.42$ & $108.00 \pm 4.44$ & 0.041 & 0.35 & 6.051 & 1.617 & 0.122 \\
\hline
\end{tabular}

*Means of three replicates \pm standard deviation, RSA: Radical scavenging activity, GAE: Gallic acid equivalent and CE: Catechin equivalent.

The highest total flavonoid content was determined in the plant extracts collected from $20^{\text {th }}$ station $(232.67 \mu \mathrm{gCE} / \mathrm{ml})$. Total flavonoid contents of the plant extracts collected from different stations showed significant differences $(\mathrm{p} \leq 0.05)$ (Table 2). Tukey multiple range test showed that the extract collected from $20^{\text {th }}$ and $10^{\text {th }}$ stations are significantly different from the others $(\mathrm{p} \leq$ 0.05). One way ANOVA observed that total flavonoid contents of the extracts collected from the stations in Burdur and Antalya provinces were significantly different $(\mathrm{p} \leq 0.05)$. Pearson correlation test showed that very weak correlation $(\mathrm{r}=0.017)$ between altitude and total flavonoid content was not found significant $(\mathrm{p}>0.05)$.

HPLC analysis presented in Table 2 shows that the highest pterosin $b$, catechin and quercetin were found in the plant extracts collected from $21^{\text {th }}$ station whereas the highest chlorogenic acid 
and caffeic acid were found in $9^{\text {th }}$ and $13^{\text {th }}$ stations, respectively. Pearson correlation test showed that negatively weak correlation $(\mathrm{r}=-0.531)$ was obtained between altitude and the amount of caffeic acid was significant $(\mathrm{p} \leq 0.05)$. There was weak correlation between pterosin $\mathrm{b}$ and quercetin $(\mathrm{r}=0.568)$ and catechin $(\mathrm{r}=0.512)(\mathrm{p} \leq 0.05)$.

It was observed that plant extracts from $22^{\text {nd }}, 9^{\text {th }}, 21^{\text {st }}, 20^{\text {th }}$ and $13^{\text {th }}$ stations have the highest radical scavenging activity and phenolic contents. Among them only $13^{\text {th }}$ station was in Antalya while others were in Burdur province.

It was found that altitude does not affect the phenolic and pterosin $b$ content of the plants which corroborates with the findings of Verma et al. (2013). Dong et al. (2011) and Uniyal (2013) also studied on the increase/decrease of some secondary metabolites which depended on the altitude.

Altitude did not affect plant phenolic and pterosin content in the present study. A. ceterach can be grown on rock cracks and the bottom of the rocks. Therefore, the chemical content of fern can be explained with soil properties, humidity, temperature, shade and sunny situations while having no relationship with altitude. Burdur and Antalya are neighboring cities and a part of Burdur province and the most of the Antalya province belong to Mediterranean Floristic Region, hence a comparison among stations would have been a better approach. Burdur province receives less rainfall in a year when compared to Antalya province. Annual precipitation averages of Burdur and Antalya provinces are $443 \mathrm{~mm}$ (Özçelik and Çinbilgel 2016) and $1062.4 \mathrm{~mm}$, according to official statistics of Ministry of Forest and Water Affairs, Meterorology General Directorate, respectively.

As Zivkovic et al. (2010) stated that chlorogenic and caffeic acids are the main phenolics of A. ceterach. It was found that these phenolicswere in higher amounts compared to other phenolics in the plant extracts and a moderate negative correlation $(r=-0.531)$ was obtained between altitude and caffeic acid $(\mathrm{p} \leq 0.05)$. It means that when the height increased, caffeic acid content decreased in plant extracts. Phenolic substances protect plants from drought stress, therefore increase in polyphenol oxidase enzyme activity indicates increase in phenolic content (Zivkovic et al. 2010).

According to field observations, sizes of fern plant were smaller in the direct sunlight than in shade because shade and bottom of rocks were rich in organic material and water. Directions were also considered to affect plant mass. Plant sizes were smaller when grown in south and west sides, but when south and west side plants were in the bottom or shade, the effects of directions were less.

There was no correlation between altitude and the other plant compounds except modarate correlation between pterosin $\mathrm{b}$ and quercetin $(\mathrm{r}=0.568)$, catechin $(\mathrm{r}=0.512)$. It means plant extracts in which pterosin $\mathrm{b}$ content is higher, have higher quercetin and catechin. Pterosins (ptaquilosides) are the fern toxins, detected in Pteridium aquilinum and carcinogenic for humans and animals (Gil da Costa et al. 2012). These toxic compounds seem to be a part of defence system of plants against predators or pathogens. Pterosin b was found in nanogram levels in A. ceterach extracts.

On conclusion, it may be said that altitude is not potent alone, but it can be a factor in occurrence of other ecological factors like soil properties, water, humidity, light and temperature.

\section{Acknowledgements}

The authors would like to express their appreciation to the authorities of the Mehmet Akif Ersoy University Scientific Research Project Commission, which supported this study (0326NAP-16). 


\section{References}

Alonso-Amelot ME, Pérez-Mena M, Calcagno MP, Jaimes-Espinoza R and Castillo U 1992. Ontogenic variation of biologically active metabolites of Pteridium aquilinum (L. Maxon), pterosins A and B and ptaquiloside in a bracken population of the tropical Andes. J Chem Ecol. 18(8): 1405-1420.

Alonso-Amelot M E, Oliveros A and Calcagno-Pisarelli MP 2004. Phenolic and condensed tannins in realtion to altitude in neotropical Pteridium spp. A field study in the Venezuelan Andes. Biochem Syst Ecol. 32: 969-981.

Alonso-Amelot ME, Oliveros-Bastidas A and Calcagno-Pisarelli MP 2007. Phenolic and condensed tannins of high altitude Pteridium arachnoideum, in relation to sunlight exposure, elevation and rain regime. Biochem Syst. Ecol. 35: 1-10.

Blois MS 1958. Antioxidant determinations by the use of a stable free radical. Nature 181: 1199-1200.

Chen CY, Chiu FY, Lin Y, Huang WJ, Hsieh PS and Hsu FL 2015. Chemical constituents analysis and antidiabetic activity validation of four fern species from Taiwan. Int. J. Mol. Sci. 16: 2497-2516.

Davis PH (ed.). 1965-1985. Flora of Turkey and the East Aegean Islands. Vol: 1. pp. 38-63. Edinburgh: Edinburgh Univ. Press.

Dong J, Ma X, Wei Q, Peng S and Zhang S 2011. Effects of growing location on the contents of secondary metabolites in the leaves of four selected superior clones of Eucommia ulmoides. Ind Crop Prod. 34: 1607-1614.

Gil da Costa RM, Bastos MMSM, Oliveira PA and Lopes C 2012. Bracken associated human and animal health hazards: Chemical, biological and pathological evidence. J. Hazard Mater. 203-204: 1-12.

Giuliani C, Maggi F, Papa F and Bini L M 2013. Congruence of phytochemical and morphological profiles along an altitudinal gradient in Origanum vulgare ssp. vulgare from Venetian Region (NE) Italy. Chem. Biodivers 10: 569-583.

Gomes T, Caponio F and Alloggio V 1999. Phenolic compounds of virgin olive oil:influence of paste preperation techniques. Food Chem. 64: 203-209.

Güner A, Aslan S, Ekim T, Vural M and Babaç MT 2012. A Checklist of the Flora of Turkey (Vascular Plants); Nezahat Gokyigit Botanic Garden Publications. Flora series I p. 3, Istanbul.

Karadeniz A, Çinbilgel İ, Şeref Gün S and Çetin A 2015. Antioxidant activity of some Turkish medicinal plants. Nat. Prod. Res. 29(24): 2308-2312.

Mahdavi M, Jouri MH, Mahmoudi J, Rezazadeh F and Mahzooni-Kachapi SS 2013. Investigating the altitude effect on the quantitiy and quality of the essential oil in Tanacetum polycephalum Sch.-Bip. polycephalum in the Baladeh region of Nour, Iran. Chin. J. Nat. Medicines 11(5): 0553-0559.

Özçelik H and Çinbilgel İ 2016. General description of the study area. In: Özçelik, H. (ed). Burdur province plant inventory (Its Economic, Rare and Endemic Plants), Culture Publications of Burdur Municipality, Burdur, pp. 1-16, (In Turkish).

Singleton VL and Rossi JA Jr 1965. Colorimetry of total phenolics with phosphomolybdic-phosphotungstic acid reagents. Amer. J. Enol. Viticult. 16: 144-158.

Uniyal AK 2013. Variation in phenol, electrical conductivity, and sugar contents in Grewia oppositifolia Roxb. J. Forestry Res. 24(1): 121-125.

Verma RS, Chauhan A, Padalina RC, Jat SK, Thul S and Sundaresan V 2013. Phytochemical diversity of Murraya koenigii (L.) Spreng. from Western Himalaya. Chem Biodivers. 10: 628-641.

Źivković S, Popović M, Dragiśić-Maksimović J, Momćilović I and Gurubiśić D 2010. Dehydration related changes of peroxidase and polyphenol oxidase activity in fronds of the resurrection fern Asplenium ceterach. Arc. Biol. Sci. Belgrade. 62(4): 1071-1081.

Zhishen J, Mengcheng T and Jianming W 1999. The determination of flavonoid contents in mulberry and their scavenging effects on superoxide radicals. Food Chem. 64: 555-559.

(Manuscript received on 23 May, 2018; revised on 18 October, 2018) 